\title{
Converging on Food Sovereignty: Transnational Peasant Activism, Pluriversality and Counter-Hegemony
}

Dr Robin Dunford

School of Humanities, University of Brighton, Brighton, United Kingdom

Rfd10@brighton.ac.uk

Acknowledgements: Thanks are due to the anonymous referee for their insightful suggestions, and to the editors of the special issue for their critical and constructive comments. All remaining errors are my own.

Dr Robin Dunford is a Principal Lecturer in the School of Humanities at the University of Brighton. 


\section{Converging on Food Sovereignty: Transnational Peasant Activism, Pluriversality and Counter-Hegemony}

This paper contributes to debates on left-wing convergence by reflecting on the convergence of a diverse transnational peasant movement around a value of and demand for food sovereignty. It reads convergence on food sovereignty through the idea of pluriversality developed by decolonial theorists. In so doing, it argues, first, that a politics of pluriversality has been key in fostering convergence on food sovereignty. Second, it suggests that convergence on food sovereignty highlights possibilities for convergence at a theoretical level across hitherto opposed decolonial and counterhegemonic positions.

Keywords: decolonial, counter-hegemony, pluriverse, left-wing convergence, food sovereignty

Diverse peasant, fisherfolk, indigenous and pastoralist associations have risen up to enact and demand food sovereignty: 'the right of peoples to healthy and culturally appropriate food produced through ecologically sound and sustainable methods, and their right to define their own food and agriculture systems' (Nyéléni, 2007). Food sovereignty calls for the food system, currently dominated by large corporations and international trade organisations, to be placed under the control of small-scale producers, gatherers and consumers. It also calls for modes of production that neither despoil nor enclose land from which rural peoples live. In developing the idea of food sovereignty, diverse activists have created, from different and potentially conflicting worldviews and interests, a convergent politics aimed at autonomy, democratic control, and social and ecological justice.

From an initial 'social base in the peasantry of the Global South and the small-scale, family farm sector of the Global North', food sovereignty has spread far and wide (Alonso-Fradejas 2015, 436), informing and being informed by activists around the world including indigenous, pastoralist, fisherfolk and environmental movements, the World 
March of Women (Masson, Paulos and Bastian, 2017), and consumer and migrant agricultural worker movements in the United States and in Europe (Brent, Schiavoni and Alonso-Fradejas, 2015; Nyéléni Europe, 2016). Food sovereignty is now entering mainstream discourse, offering a rival to the common sense according to which mass production and industrial agriculture is key to feeding the world. La Via Campesina and the International Planning Committee for Food Sovereignty have used their position in the Civil Society Forum of the UN Food and Agriculture Organisation to claim that small producers can feed the world whilst cooling the planet (LVC, 2009); a claim that has been endorsed by successive UN Special Rapporteurs on the right to food. The growth of the food sovereignty movement, the convergence of feminist, environmentalist, peasant, pastoralist, indigenous and fisherfolk movements on food sovereignty, and food sovereignty's challenge to and transformation of global discourses suggests that activists are forming a counter-hegemonic movement, challenging and providing an alternative to a common sense of mass production and trade. Whilst the hegemony of a market-based, agro-industry dominated food system remains, a rival is emerging.

La Vía Campesina, a network of 182 peasant organisations that now brings together over 200 million peasants across 81 countries and five continents, has been at the centre of the emergence of food sovereignty. As a network that was transnational from its inception, La Via Campesina brings together movements that are inspired by a range of practices and ideological perspectives: liberation theology and education, indigenous modes of conflict resolution, deep ecology, feminist praxis, agrarian Marxism, anarchist organising principles, and more liberal approaches to reform and advocacy, to name a few. Despite this diversity, La Via Campesina has overcome the fragmentation so common amongst social movements. This paper uses convergence on food sovereignty as a lens through which to contribute to theoretical debates on left-wing convergence (Coleman and Rosenow, 2016; Prichard and Worth, 2016). It does so by reading convergence on food sovereignty in terms of the idea of pluriversality developed by decolonial theorists (Alcoff, 2012; Conway and Singh, 2011; Dussel, 2013; Grosfoguel, 2012; Mignolo, 2011). Whilst this idea arose in decolonial theory rather than food sovereignty activism, it was inspired by the practices of peasant, indigenous and other grassroots movements in the Global South. 
The paper makes two arguments. First, a politics of pluriversality has been key in fostering convergence on food sovereignty. Second, convergence on food sovereignty highlights possibilities for convergence across hitherto opposed decolonial and counterhegemonic positions. After outlining the Western focus of the left-wing convergence debate, the first section introduces counter-hegemony, pluriversality, and the perceived tensions between the two. Pluriversality refers both to a process of intercultural dialogue across diverse worldviews and to a value of a world in which many worlds fit. The third section explores convergence on food sovereignty, showing how these two features of pluriversality have been key in articulating diverse groups behind common values and demands. The concluding third section then suggests that convergence on food sovereignty cuts through theoretical tensions between pluriversality and counterhegemony.

\section{Left-Wing Convergence, Counter-Hegemony and Pluriversality}

Divisions amongst the left barely need repeating. All too familiar are debates between advocates of a politics of 'exodus' - of escaping the existing order in order to build a new society in the shell of the old (Hardt and Negri, 2005), and advocates of counterhegemonic engagement - engaging with, with a view to taking over and transforming, existing institutions (Mouffe, 2008). Far from being solely theoretical, similar debates raged in and around the Occupy movement, playing out through disagreements over whether occupiers should formulate demands to make of authorities or refuse to recognise the legitimacy of existing institutions and create a prefigurative example of a new society. Familiar, too, are disputes over whether the left should pursue a horizontalist politics in which diverse and separate struggles maintain their specificity, or adopt a verticalist politics of hierarchical organisation, forming a single party able to organise struggles, create an affective sense of belonging, and take power (Dean, 2016).

Focus on left-wing convergence in practice can and has helped bridge these positions, showing how apparent theoretical divides are reconciled in practices combining exodus and engagement and in organisational forms that combine leadership with respect for horizontalist principles (Kiersey and Vrasti, 2016; Teivanen, 2016). So far, though, work on left-convergence has focused primarily on Western movements, organisations, and traditions of thought (see, i.e., Kiersey and Vrasti, 2016; Maiguashca, Dean and Keith, 
2016; Prichard, Kinna and Berry 2012; Vey, 2016. For an exception, see Teivanen, 2016). The absence of a wider perspective could limit understandings of the problems faced by, and potential avenues for convergence across, the left. To give an example, Dean (2016, p.3) lambasts the individualism of the contemporary left and its mantra, captured in the words of a 'thin young man with curly hair and a revolutionary look' speaking during Occupy Wall Street protests, that 'no one can decide for you. You have to decide for yourself. Everyone is an autonomous individual'. Dean (2016, p.67) suggests that the broad view that underlies this mantra, namely, that 'collectivity is undesirable and that collectivity is impossible', is a major limit holding back populist, liberal, progressive, trans, pluralist, green, multiculturalist, anti-racist, radical democratic, feminist, identitarian, anarchist, queer, autonomist, horizontalist, anti-imperialist, insurrectionist, libertarian, socialist, and communist left-wing positions. To address this fragmentary individualism, the left should return to a party form, Dean argues, drawing lessons from the history of the US communist party. In the Global South, movements have broken down this individualism vs. party dichotomy by developing collective forms of organisation that have generated social and political change without depending on a party form (Motta and Nilsen, 2011).

Insofar as ideas and strategies developed through engagement with Western movements and thought are proposed as universal solutions for a globally ailing left, they would rightly become subject to criticisms of 'epistemic ethnocentrism' that decolonial thinkers have levelled at parts of the Euro-American left (Mignolo, 2002, p.66). Hierarchies of knowledge production have been an important factor underpinning five centuries of colonial power (Dussel, 2013; Grosfoguel, 2012; Mignolo, 2011). With partial and Eurocentric accounts of Western societal development considered to provide a model for the rest of the world, purportedly universal accounts of what it means to be "civilised" or "developed" have been enforced violently, with the aid of political, military and economic power. With Western knowledges universalised, perspectives from most of the world are regarded to provide, 'at best', 'practical and local forms of knowledge', subordinate to the West's purportedly universal and globally applicable knowledge (Santos, Nunes and Meneses, 2007, p.xxxv). At worst, they represent "uncivilised", "backward” worldviews; obstacles to progress that must be destroyed, often violently (Grosfoguel, 2012). Despite commitment to emancipation, some leftist traditions have reproduced such knowledge formations. As Grosfoguel (2012, p.6) has argued, 'Marx thinks', and perhaps most 
notably, the orthodox Marxists that Marx himself rejected think, 'from the historicosocial situation of the European proletariat'. In light of the problems faced by, and opportunities available for, urban industrial workers - or perhaps now urban immaterial workers - some Marxists continue to propose 'a global/universal design' of urban proletarian revolution 'as the solution to the problems of all humanity' (Grosfoguel, 2012, p.6).

To ensure that these problems are not reproduced in work on left-wing convergence, this article reads the convergence of a transnational food sovereignty movement through the lens of decolonial thought. Bringing decolonial thought to the table brings with it arguments concerning the compatibility of counter-hegemony and pluriversality. My hope, here, is to foster convergence across this potential divide, showing how convergence on food sovereignty combines pluriversality and counter-hegemony.

\section{From Counter-Hegemony to Pluriversality}

Believing that diverse struggles operating separately will lack sufficient strength, counterhegemonic theorists suggest that practices of resistance must be integrated into a strategically coherent form' (Carroll, 2006, p.1). Put differently, varying and sometimes conflicting demands and struggles must be 'articulated politically' around a common set of demands and 'a common identity, a "we", which 'requires the determination of a "they"' (Mouffe, 2008, p.5). This strategic form need not be that of Dean's singular party. Indeed, depending on the form it takes, such a party may falsely unify different demands. To ensure that a common identity and demand does not erase the diversity and difference of the groups that stand behind it, Laclau and Mouffe (1985) propose that it coalesce around an empty signifier, a term that does not relate to a signified entity like a social class or identity grouping, and can hence draw together a wide range of groups. Counterhegemonic theorists also propose a strategy of engaging with the existing hegemonic order in order to 'establish a' new, 'more progressive' order (Mouffe, 2008, p.3). Finally, any social and political order is undergirded by a "common sense" set of assumptions and knowledges that come to appear natural, even if they are contested on the margins. A counter-hegemonic politics seeks to denaturalise these knowledges - like knowledges concerning the purported necessity of growing more food through industrial methods to feed the global population - and replace them with a new common sense. 
Decolonial critiques relate in part to the way in which counter-hegemonic ideas are constructed and justified. Conway and Singh (2011, p.692), for example, argue that Laclau and Mouffe's politics is 'situated squarely within a history of Western modernity', and based on a reading of the Western democratic tradition that 'bracket[s]' its 'intertwined history with, legitimations of, and key complicities with, capitalist rule and expansion'. The critique also relates to the above core features of counter-hegemonic politics. Grosfoguel argues that counter-hegemonic unity 'is always hegemonized by a particular that becomes the representative of all forms of oppression against a common enemy, but which does not incorporate each particularity into itself' (Grosfoguel, 2012, p.98). Positive identities and demands will, Grosfoguel suggests, not adequately represent the various movements and struggles that they purport to bring together, 'instead dissolving these into the abstract universal of the empty signifier'. Grosfoguel's (2012, p.98) worry is that this empty signifier will merely reproduce the 'abstract eurocentred universalism in which a particular presents itself as representative of all particularities without representing them in their plenitude'. As such, counter-hegemonic demands will replicate the form of other universals - of "civilisation", "development" and even of industrial proletarian led revolution - that have been felt as forms of oppression. Conway and Singh (2011, p.693) add to this critique, suggesting that such a politics also 'reifies and universalises a singular ontology of the political, that of the struggle for hegemony'. In so doing, it assumes that effective change can only be achieved simultaneously and en mass, potentially ignoring alternatives that grow and develop non-simultaneously and without mass organising. Decolonial theorists, then, reject 'those abstract universals of the empty signifier which characterise the hegemonic process of Laclau and Mouffe', claiming that, whilst we need a way 'to identify friends and enemies', 'we need to avoid...the kind of positive universality about solutions where one defines for the rest what is 'the solution' (socialism, communism, radical democracy, etc.)' (Grosfoguel, 2012, p.101).

In place of abstract universals, decolonial theorists have introduced pluriversality - the idea of a world in which many words are possible. Pluriversality refers, in one sense, to the process through which values, ideas, and principles are constructed. A value is pluriversal if it emerges from dialogue across multiple worldviews and cosmovisions, and hence emerges not as a particular perspective is imposed as a globally salient idea, but 
through communication across multiple people(s) in diverse places. Pluriversality also refers to a substantive value of a world in which many worlds fit. As a value itself, pluriversality draws into relation principles of non-domination, equality, difference, and autonomy (on non-domination and anarchist thought, see Kinna and Prichard, forthcoming). It is 'grounded in daily life and the dominant models prevalent in that context' - in the experience of injustice in the face of the destruction of multiple worlds (Dussel, 2013, p.xvi). As such, it rejects forms of domination that arise as particular values and ways of living are imposed as a singular, universal and global design, be it the global design of "civilisation", a particular model of "development", or a food system that forces producers to leave the land or become adversely incorporated and forced to produce single crops like coffee and cocoa for export (Martínez-Torres and Rosset, 2010). It is also based on an understanding of the inseparability of equality and difference. 'A world in which many worlds are possible...means that people and communities have the right to be different precisely because we are all equals' (Mignolo, 2000, p.311). If we don't take difference seriously, and, to give an example mentioned later, do not take seriously those that call for respect for mother earth or those that value roaming across land, then we do not treat these people(s) as equals. To treat people(s) as equals, then, is to take seriously difference and ensure a world in which many worlds can fit. Finally, the value of pluriversality recognises that some groups, including some indigenous peoples, 'want disengagement and autonomy more than anything else' (Alcoff, 2012, p.64). It thus remains open to the idea of a plural world, where decision-making and governance need not be vested in a single authority - be it at nation-state or global level - provided that these different authorities do not undermine the autonomy of others by preventing a world in which their other worlds are possible.

At this point, two concerns around pluriversality arise. In taking difference and autonomy seriously and calling for a world in which many worlds fit, does pluriversality provide a cover for or prevent criticism of oppressive practices adopted and accepted by particular communities? No. As shall become clear in the final section, pluriversality as a substantive value of a world in which many worlds fit rules out any practices - patriarchal, fascist or otherwise - that systematically shut down possibilities for others.

Second, and from a counter-hegemonic perspective this time, does the absence of a positive universality about solutions result in a series of fragmented struggles operating 
separately, without the unity and common purpose needed to become a powerful actor able to generate enduring change? One response to this second concern is to say that diversity is not dangerous. 'Diversity simply is', and 'differences', Conway and Singh (2011, p.698) argue, 'do not require the dogmatic signifier of hegemony in order to articulate themselves politically'. Commonly cited examples of this anti-hegemonic politics are the attempts, of Zapatista's and of World Social Forum activists, to foster a convergence of movements 'without the philosophical agreement, unified political project, and coherent political organisation that has been commonly imagined as necessary to contesting hegemony on the terrain of the national-political (and now projected onto the global) scale' (Conway and Singh, 2011, p.697). The 'articulation of difference' in the World Social Forum is 'often oriented towards defending localised lifeprojects and life spaces, not towards gaining hegemony over the whole of society' (Conway and Singh, 2011, p.698). Such place-based projects are vitally important. Indeed, diverse place-based projects form the heart of a pluriverse - a world in which many such worlds fit. Place-based projects, though, remain vulnerable to power dynamics at national and global levels that lead to dispossession, displacement, the criminalisation of activism and oppression. It is in part for this reason that counter-hegemonic thinkers have suggested - whether fairly or otherwise - that the World Social Forum is a 'funfair for the expression of ideas', rather than a movement that can provide a meaningful challenge to dominant global orders (Worth and Buckley, 2009, p.649; for a different perspective see Santos, 2008).

Despite the clear similarities between the food sovereignty movement's embrace of different ways of living from the land - discussed in the next section - and the World Social Forum's embrace of the other worlds that are possible, there is a key difference; a difference which highlights possibilities for convergence across pluriversality and counter-hegemony. Organisation, dialogue and exchange across peasant movements has led to the articulation of a positive vision that can be fought for, enacted and demanded, and that is emerging as a rival to a common sense according to which technologically driven mass production and market access are the key to feeding the world and escaping rural poverty. This vision provides not only a way of identifying friends and enemies, but also a positive vision around which a growing movement is converging. This positive vision, though, is not an abstract universal, imagined in advance from one place. Nor is it an empty signifier. As shall become clear in the remainder of the article, it is a rich vision 
developed through dialogue across multiple cultures and cosmovisions. In articulating a growing movement around such a vision, food sovereignty activists have showed how pluriversality and counter-hegemony can be reconciled in practice.

\section{Converging on Food Sovereignty}

That a vast array of rural movements has converged on food sovereignty is remarkable. As well as overcoming the problem of organising dispersed rural people(s), the movement has avoided fragmentation through conflict. How have diverse actors converged on food sovereignty? One - typically Marxist - way of answering this question would be to focus on the material factors that tie interests together. As has been documented extensively (i.e., Martinez-Torres and Rosset, 2010), land grabs, environmental decline and unfair terms of trade serve to clear peasant, indigenous, pastoralist and fisher people(s) from their land or waters. Moreover, in light of the dispossession of those producing varied and healthy foods in favour of monocrops for mass production, 'clear linages exist between the dispossession of peasant and indigenous communities in the global South and the epidemic of diet-related diseases in low-income communities of colour in the US' (Alonso-Fradejas, 2015, p.437). Important as these material factors are, histories of leftwing fragmentation and internal class disputes tell us that common sources of oppression do not automatically give rise to a counter-movement. That convergence has happened requires explanation at the level of social movement practice; an explanation that, as Anarchists and Liberation thinkers have long pointed out, must take into account the organisational and pedagogical practices of social movements and the ethical concerns of their members. To this end, this section outlines three factors that have been key in ensuring convergence in practice. First, potentially opposing practices of 'exodus' and 'engagement' have been combined in a manner that builds the strength of the movement. Second, the organisational structures of the movement combine solidarity building with an ability to scale action transnationally. Third, and the main focus here, pluriversal practices of intercultural dialogue have helped create a vision of food sovereignty that is shared by people with potentially conflicting visions of living from the land.

\section{Exodus and Engagement:}

Practices of the food sovereignty movement have cut through debates on the left between advocates of 'exodus' - exiting from existing arrangements to build a new society, and 
'engagement' - engaging with, with a view to taking over, existing institutions. In so doing, they have brought together movements that prioritise direct action and movements that focus primarily on advocacy work. Food sovereignty is enacted in the here and now. To use a phrase coined by the anarchist Industrial Workers of the World union, food sovereignty involves building the new society in the shell of the old. To this end, social movements occupy land and grow food as a means of taking for themselves democratic control of the food system (Purwanto, 2013; Starr, Martínez-Torres and Rosset., 2011). They also share knowledges and seeds as a means of maintaining the ability of people to produce food through ecologically sound and sustainable methods (Holt-Giménez, 2010). La Vía Campesina will soon have over 40 peasant agroecology training schools across five continents (Rosset and Martínez-Torres, 2012), helping to restore knowledges of different ways of living from the land that have been lost through the intensification of industrial agriculture.

This does not mean that food sovereignty is a politics of 'exodus' (Hardt and Negri, 2005). The food sovereignty movement have also engaged with institutions both antagonistically and constructively. Through an annual day of peasant struggles and involvement in a range of local, national and global protests, food sovereignty activists make clear their opposition to agro-industry, land grabs, and intellectual property laws that prevent seed-sharing. Through consistent pressure on and constructive engagement with governments and international institutions, food sovereignty has been incorporated into a growing number of national constitutions (including in Bolivia, Ecuador and Nepal) and national laws (including in Mali and Senegal) (Bellinger and Fakhri, 2013). Internationally, La Via Campesina's persistent activism within the United Nations (UN) Food and Agriculture Organization and Human Rights Council has resulted in a proposal for a declaration of peasants' rights, expected to be finalised and adopted in the near future, which outlines a series of rights through which food sovereignty could be realised (LVC, 2017). Whilst these new laws and aspirational rights principles will not automatically instantiate food sovereignty, they provide tools that might be used to legitimise land occupations and protests and provide leverage in future advocacy work. They therefore form part of a wider 'strategic vision' of supporting further advocacy work and giving legitimacy to direct actions including land occupations. By being part of such a vision, new institutional principles can support ongoing 'social mobilisations' in which people enact their alternative ways of living from the land (Paul Nicholson, founding 
member of La Via Campesina, interviewed in Wittman, 2009, p.679). Strategies of exodus and engagement thus go together, with engagement with institutions strengthening 'attempts to build the alternative livelihoods that sustain real, existing alternatives.

\section{Organisational Structure}

La Via Campesina was formed in 1993 by a group of farmers' organisations with the aim of connecting peasant and farmer organisations to provide a challenge to a globalised food system. They reject rigid and hierarchical structures and, in response to 'smooth talking politicians and nongovernmental organisations' that purported to represent the interests of the peasantry, seek to provide avenues through which peasants can speak for themselves (peasant leader, interviewed in Martínez-Torres and Rosset 2010, p.164). But they do not eschew leadership and representation. So doing would, as Teivanen (2016) argues, exclude from the movement those that cannot travel to arenas in which they can represent themselves and make impossible meaningful activism at a transnational scale. Instead, La Via Campesina develop forms of organisation and leadership that place grassroots voices at their heart and continue to challenge the emergence of hierarchy. Their highest decision-making body is the International Conference, which takes place roughly every four years, bringing together hundreds of peasant activists from the various member organisations. To challenge potential gender and age-based hierarchies, each member organisation is expected to bring a delegation that contains at least $50 \%$ women and 33\% youth representation, and separate women's and youth assemblies take place ahead of the conference (LVC, 2017).

The conferences begin with a Mistica, a ceremony involving imagery of soil, water, and seeds. These build a sense of solidarity and commonality by enabling direct, un-translated communication across people who speak different languages and by generating an affective sense of belonging (Martínez-Torres and Rosset, 2010). The conferences also involve working group discussions and wider discussions. By meeting and sharing stories across cultures and worldviews, it becomes possible for attendees to recognise and understand links between their oppression and the oppression of others in distant locales. International meetings are, then, key in ensuring that common sources of oppression in the form of land grabs, corporate dominance and unfair trade are recognised by the actors concerned. The conferences lead to a statement on what the movement stands for and 
make decisions, through consensus where possible, on the priorities and strategies of the movement. Between conferences, an International Coordinating Committee performs the day-to-day work of ensuring that the solidarity and shared demands developed through meetings are acted upon. The Coordinating Committee consists of two representatives one male and one female - from each of La Via Campesina's nine constitutive regions. Finally, and echoing long-standing anarchist forms of organisation, the international secretariat moves every four years in order to avoid the hierarchies of place in which the movement represents one region more than others.

\section{Pluriversal Dialogue}

In addition to scaling peasant voices transnationally and building solidarity, these structures allow La Vía Campesina - sometimes in co-ordination with other networks to operate as an 'arena for action' in which common values and demands are forged (Borras Jr. 2010, p.779). This arena for action is one in which pluriversal practices of intercultural dialogue take place, helping to develop a vision of food sovereignty around which potentially conflicting groups can converge. As Martínez-Torres and Rosset (2014) have argued, a process of diálogo de saberes - dialogue among and across different knowledges - has been central in managing possible conflict and in building 'unity in diversity' (Desmarais, 2007). This dialogue begins from a position of respect for multiple knowledges and traditions. Resonating with the criticism of Western universals in decolonial thought, it is not presumed that one knowledge, derived from one social and geopolitical location, can have all the answers. In addition, dialogue is not oriented towards bargaining amongst already-given interests with a view to reaching a compromise or middle ground. Instead open and horizontal dialogue across those with different knowledges and comsovisions, especially those that have historically been marginalised, is used to develop new ideas, proposals and values.

As discussed shortly, this process sometimes leads to agreement on values, priorities and practices. At other times, conflict and disagreement is not easily resolved. When this is the case, divisive issues are parked for later so that discussion and planning can continue in relation to other issues on the table (Martínez-Torres and Rosset, 2014). As Ibrahima Coulibaly, President of the National Coordination of Peasants' Organisation of Mali (in Nyéléni, 2007, p.20) points out, the food sovereignty movement adopt a pragmatic 
approach, recognising that 'we have many problems and we don't have time to lose by discussing theoretical questions. We must resolve our problems'. This is not to say that the movement is non- ideological. Rather, it is to say that a conscious effort is made to ensure that the ideological diversity of the movement does not prohibit convergence in practice. 'The internal culture' in La Via Campesina 'is such that the members do not push any given contradiction to the point of rupture' (Martínez-Torres and Rosset, 2014, p.13). After time has passed and things have worked themselves out in the background, discussion on controversial topics begins again at later meetings.

This 'peasant, indigenous or community way of resolving conflicts' and building dialogue has been central in allowing for convergence (Martínez-Torres and Rosset, 2014, p.12). To give an example, one potential line of tension within the food sovereignty movement stems from differences between demands - commonly made by peasant and family farmers - for privately-owned, parcelled off land on the one hand and visions of territory embraced by indigenous peoples and pastoralists on the other. As is clear from violent conflict in Darfur and elsewhere, tensions between pastoralists who roam across land and farmers who want sole, private access can be devastating. Where some may want to own their land, put fences around it, and do as they see fit on it, others may have concern for access rights across a wider territory; access that may require passing through land used by others. In its initial formulation, food sovereignty was closely tied to the concerns of peasant and family farmers. It was focused on issues including land reform, government support for smallholders, and national control over trade. Whilst environmental justice and ideas of shared territory were present, they were less central to the overall framing of food sovereignty. Many Via Campesina member organisations called for 'more credit, subsidised agrochemicals, and machinery for peasants' (Rosset, 2013, p.727), and peasants who acquired land through land occupations would often copy dominant models of production by using 'purchased chemicals, commercial seeds', and ‘heavy machinery' (Rosset, 2011, p.162; Fernandes Welch and Gonçalves, 2010).

At a "Land, Territory and Dignity" forum in Porto Alegre in 2006, La Via Campesina 'really engaged with the non-peasant peer actors who share the rural territories that are contested in struggles for agrarian reform' (Rosset, 2013, p.724). Such engagement generated awareness that land reform, if solely focused on the interests of peasants and family farmers, could result in the enclosure of land used by nomadic pastoralists and 
indigenous peoples. Moreover, if peasants reproduce agribusiness models, there is a risk that they could continue to degrade soils and that their seeds and fertilisers could spread to nearby land, generating problems for those who engage in different - perhaps low technology and organic - forms of production in the wider territory. Instead of leading to the arguments and fragmentation that are all too familiar on the left, intercultural dialogue across peasant, indigenous and other actors in Porto Alegre led to a growing recognition of this potential problem and, ultimately, to a renewed vision of agrarian reform and food sovereignty. To this end, statements agreed at the Porto Alegre forum insisted that agrarian reform 'must include the cosmovisions of territory of communities of peasants, the landless, indigenous peoples, rural workers, fisherfolk, nomadic pastoralists' and others who 'maintain a relationship of respect and harmony with the mother earth' (Land, Territory and Dignity Forum, 2006).

Pluriversal dialogues continued a year later in February 2007 at the Nyéléni forum, organised by La Via Campesina and a range of other organisations including the International Planning Committee for Food Sovereignty, the World Forum of Fisher Peoples, the World March of Women, and Friends of the Earth. The forum brought together people from up to 80 different countries, including youth and elders, Atheists, Christian's, Hindu's, Muslim's, Animist's and Mayan's, the landed and the landless, to name just a few (Martínez-Torres and Rosset, 2014, p.979). Expanded dialogue at Nyéléni resulted in a declaration on food sovereignty that continues to be regarded as the key document outlining what food sovereignty stands for. Ideas of shared territory and environmentally friendly production became central elements. The Nyéléni forum had working groups on sharing territories, which came to the collective view that territories go 'beyond geopolitical boundaries so as to include the territories of indigenous peoples, nomadic and pastoralist communities, and beach-based fisherfolk'. They emphasised 'the holistic nature of territories as including land, water, seeds, livestock breeds and aquatic organisms' (Nyéléni, 2007, p.35). Embracing indigenous and other visions of territory means not seeing land and nature as resources to be exploited or used to produce food, but thinking of territories as spiritually significant and interconnected, with what happens on even a privately-owned parcel of land having effects on the wider territory of which it is part. With the fundamental interconnectedness of territories and the people living from them in mind, Pachamama or Mother Nature ought to be treated with respect, and production and gathering from land should be done in an ecologically sensitive 
manner. For otherwise, the actions of some in enclosing land, degrading soil and using genetic seeds that spread will undermine the livelihoods of others, and hence shut down possibilities for a pluriverse.

The dialogues at Nyéléni and elsewhere have led to a renewed concept embracing, amongst other things, local knowledges, shared territories, and the importance of environmentally friendly food. This new vision has been constructed not through a simple addition of new demands but through a change to the overall meaning of food sovereignty. Where, before, food sovereignty was focused on a right to produce ones own food on ones own territory, it has since become a vision that has respect and harmony with mother earth at its heart. The changing meaning of food sovereignty has had significant effects on peasant movements, including the Movimento dos Trabalhadores Rurais Sem Terra (MST) in Brazil, who previously brought 'the model of agribusiness into our own house' by seeking access to fertilizers, GM seeds, and energy-intensive inputs (MST, cited in Rosset, 2013, p.727). In light of the intercultural dialogues in Porto Alegre, Nyéléni, and a range of other locations since, 'almost all LVC organizations', including the MST, "now promote some mixture of agroecology and traditional peasant agriculture' (Rosset, 2013, p.727). As a result, the demands of some groups - for forms of agrarian reform that can lead to enclosure, and for the ability to pursue forms of production that negatively affect surrounding land - have been changed to incorporate more inclusive visions that are compatible with multiple ways of living from land. It is through this process that food sovereignty has become a pluriversal value - one that embraces the different "worlds" of family farmers, fisherfolk, indigeneous peoples, and others. This is not to say that the project of developing a pluriversal value of food sovereignty is complete. Significant challenges remain. For instance, whilst gender has become a mobilising ideology in the food sovereignty movement and gender equality is built into organising structures, there is still work to do in developing specific measures to address gender inequalities in food and agriculture (Agarwal, 2014; Park, White and Julia, 2015). Moreover, it is not clear where agricultural labourers who do not seek their own land fit within the vision of food sovereignty, and the 'role of food workers' is 'even less well articulated' (Brent et al., 2015, p.626). The methods adopted so far, though, provide reason for optimism that these issues can and will be addressed collectively within the movement. 
The construction of a pluriversal value through pluriversal dialogue has been central to convergence on food sovereignty. With visions of territory incorporated alongside demands of peasants for parcels of land, indigenous and pastoralist groups can fully support food sovereignty. And with sustainability incorporated at the heart of the idea of food sovereignty, environmental movements and "ethical" consumers have been able to find a value that speaks to their concerns. As a result, Nyéléni, together with meetings leading up to it, created an enlarged 'global food sovereignty movement' (Wittman, Desmerais and Wiebe, 2010, p.7); a global movement that has been able to build food sovereign alternatives, challenge the common sense according to which industrial agriculture is the only way to feed the planet, and fight for new laws and rights. Through dialogue across multiple worldviews, food sovereignty has come to 'reflect the historical and political circumstances of different people' (Leventon and Laudan, 2017, 25), enabling the food sovereignty movement to 'grow in our struggle' not in spite of the multiple cultures and cosmovisions that form part of it, but 'thanks to the exchange among cultures... [and] the diversity of our peoples' (LVC, 2012).

\section{Concluding Remarks: Pluriversality and Counter-Hegemony Revisited}

Processes of pluriversal dialogue do not explain fully convergence around food sovereignty, nor how food sovereignty has emerged as a counter-hegemonic alternative. Such explanation requires a detailed and lengthy analysis of the practices of the hundreds of grassroots movements involved in the struggle for food sovereignty, much of which has been provided elsewhere (see, i.e. Brent et al., 2015; Desmerais, 2007; Holt-Giménez, 2010; Martínez-Torres and Rosset, 2010; Purwanto, 2013; Starr et al., 2011). Rather than repeat these analyses I return, in this concluding section, to perceived theoretical tensions across decolonial and counter-hegemonic positions, arguing that the food sovereignty movement reconcile these tensions in practice.

The first section highlighted the dual aspect of pluriversality - pluriversality as a process of intercultural dialogue and pluriversality as a substantive value of a world in which many worlds fit. The dual aspect of pluriversality is a source of ambiguity in decolonial thought; an ambiguity that helps understand both its rejection of counter-hegemonic thought and the possibility of convergence across decolonial and counter-hegemonic positions. When pluriversality as a process is taken as a guide, decolonial thought tends 
to be presented as 'just an option' to add to other political, moral and analytical positions, and not 'the one' counter-hegemonic option (Mignolo, 2011, p.21).

what we put on the table is an option to be embraced by all those who find in the option(s) a response to his or her concern and who will actively engage, politically and epistemically, to advance projects of epistemic and subjective decolonisation (Mignolo, 2011, p.xxvii).

On this reading, Westernised leftist visions, amongst other visions criticised in decolonial thought, also offer 'one among many options, and not the one guide to rule the many' (Mignolo, 2011, p.176). When thinking about pluriversality as a process of intercultural dialogue, this makes perfect sense. It would be wrong to set out, in advance, one option that should guide all others. To do so would undermine the very process of open exchange and dialogue across cultures and cosmovisions. If focus falls on this dialogic aspect of pluriversality alone, counter-hegemony becomes problematic. To recall Grosfoguel's (2012, p.101) claim, any 'positive universality about solutions' would close a space for others with different perspectives and worldviews, and hence lead to an exclusionary politics in which some define 'for the rest what is 'the solution'. Decolonial thought and ideas of pluriversality, so construed, should not make a hegemonic move of becoming the option or the idea around which a cohesive movement could be articulated. In addition to rendering pluriverality incompatible with counter-hegemony, this reading of pluriversality solely as a process of dialogue brings normative problems. When focusing on pluriversality in this processual sense, it is not clear how pluriversality would make possible a condemnation of viewpoints that are sexist, racist, imperialist, and so on. Would these, too, have their seat at the table, and not be ruled out by any positive universality about solutions?

Aware that this weaker version of decoloniality risks 'losing the ability for critique' (Alcoff, 2012, p.6) and constraining any ability to move beyond the fragmenting "no one can decide for you" attitude of Dean's man with a revolutionary look, decolonial thinkers sometimes adopt a different approach. Mignolo (2011, p.292), for instance, also claims that 'pluriversal futures... are only possible if the reign of economic capitalism ends'. Economic capitalism provides space only for practices that can be turned into, or do not obstruct, profits, and hence does not allow other worlds to exist on equal terms (see also 
Dussel, 2013, p.138). Setting aside the question of whether this is an empirically true statement about capitalism, the point here is that if a given system, practice or worldview systematically rules out or marginalises other ways of living, practices, or worldviews, then it is not compatible with a world in which many worlds fit. This perspective follows when the substantive value of pluriversality is taken as a guide. Some worldviews, including those that suggest that 'underused' and 'unproductive land must be used to produce more food even if that means enclosures and the removal of people from land (see, i.e., World Bank, 2009, p.175) - and some practices, including modes of production that result in the degradation of surrounding territory - do not allow for a world in which multiple ways of living from the land can exist. Instead, they create a monoculture in which only a few can decide what food is grown and how. They therefore do not meet the test of pluriversality as a value. Focusing on pluriversality as a value, it becomes clear that pluriversality and decoloniality amount to a project that 'all contending options would have to accept' (Mignolo, 2011, p.23).

When understood in this way, decolonial thought provides means for normative critique and requires an exclusionary differentiation of us from them, of acceptable positions from unacceptable positions. It involves rejecting and considering as not an option - though without necessarily excluding from dialogue in advance - those viewpoints and practices that systematically shut down other worlds. And it involves calling for a new order in which many worlds are possible. Through reflecting on pluriversality as a value, then, we return to features - of the necessity of exclusion, of standing together against a prevailing order, and of the call for a new order - that lie at the heart of a counter-hegemonic politics. And this is something that the food sovereignty movement have embraced. Discussion at Nyéléni (2007) was focused not only on 'what we are fighting for', but also on 'what we are against' and 'what we will do'. The idea of a pluriverse, then, provides a way of maintaining a co-ordinated movement, showing solidarity in its common rejection of views and practices that do not allow multiple ways of living from land, and gathering behind a common demand for a new order - in this case, a new global food system guided by principles of food sovereignty. In this respect, the vision of food sovereignty is exclusionary and identifies enemies: those who facilitate land grabs in the name of rendering productive "underused" land; those that pollute in a manner that destroys the livelihoods of others; trade rules that allow food to be "dumped" in local markets in a manner that makes it impossible for small-scale farmers to compete; and so on. The above 
actors and rules are condemned precisely because they systematically shut down alternatives and do not allow for the coexistence of different "worlds" of living from land. They are, as a result, not compatible with a pluriversal value of food sovereignty. And yet, pluriversality remains radically committed to diversity. It does not require that people are part of a single party or identity, with a single goal, precisely because a pluriversal world - like the world of food sovereignty - is one in which multiple options remain possible.

Whilst focus on pluriversality as a process risks a fragmented, "no one can decide for you" politics, a sole focus on pluriversality as a value could produce a new abstract universal - albeit one that calls for respect for difference. This would undercut the wider decolonial project of restoring marginalised voices and widening sources of knowledge. The practices of the food sovereignty movement discussed here show how the two aspects of pluriversality can be brought together in practice. A process of intercultural dialogue has developed ideas, values and plans for action that help construct a world in which many worlds exist. Through dialogue across peasant, fisherfolk, indigenous, pastoralist, environmentalist, and feminist organisations, the food sovereignty movement has come up with a principle that ensures that the "worlds" and cosmovisions of smallholder farmers remain compatible with the use of territory by pastoralists and grazers, respect indigenous cosmovisions of harmony with mother nature, and embed practices enhancing environmental protection and gender equality. It is through intercultural dialogue that activists have been able to work out a principle, value and practices that allow for a multiplicity of ways of living from the land. Moreover, intercultural dialogue has been used in order to construct demands - for peasants' rights, for food sovereignty laws, for land reform, and so on. It has been used to build strategies for making people listen and respond to such demands. Pluriversal dialogues, and a resulting pluriversal value, have been at the heart of a counter-hegemonic project. The counter-hegemonic politics of food sovereignty differs, though, from the counter-hegemonic politics of the empty signifier proposed by Laclau and Mouffe and criticised by Grosfoguel and Conway and Singh. Food sovereignty is not an empty signifier, but a signifier rich with the content of intercultural dialogue across cultures. And it is with this rich, diverse content and commitment to a multiplication of perspectives in mind that food sovereignty remains an open, evolving principle, that has been and will continue to be further developed through future intercultural dialogue. 


\section{Bibliography}

Alcoff, L.M. (2012). Enrique Dussel's transmodernism. Transmodernity: Journal of Peripheral Cultural Production of the Luso-Hispanic World, 1(3), 60-68

Agarwal, B. (2014). Food sovereignty, food security and democratic choice. The Journal of Peasant Studies, 41(6), 1247-1268.

Alonso-Fradejas, A., Borras Jr, S.M., Holmes, T., Holt-Giménez, E., and Robbins, M.J. (2015). Food sovereignty: convergence and contradictions: conditions and challenges. Third World Quarterly, 36(3): 431-448

Bellinger, N. and Fakhri, M. (2013). The intersection between food sovereignty and law, Natural Resources \& Environment 28(2), 1-4

Borras Jr, Saturnino M. (2010). The politics of transnational agrarian movements. Development and Change, 41(5), 771-803.

Brent, Z.W., Schiavoni, C.M. and Alonso-Fradejas, A. (2015). Contextualising food sovereignty: the politics of convergence among movements in the USA. Third World Quarterly, 36(3), 618-635.

Carroll, W.K. (2006). Hegemony, counter-hegemony, anti-hegemony, Keynote address to the Annual Meeting of the Society for Socialist Studies. York University, Toronto,

June 2006. Available at https://www.socialiststudies.com/index.php/sss/article/view/23790/17675, accessed on 10 August 2017.

Coleman, L.M., and Rosenow, D. (2016). Security (studies) and the limits of critique: why we should think through struggle. Critical Studies on Security, 4(2), 202-220.

Conway, J. and Singh, J. (2011). Radical democracy in global perspective. Third World Quarterly, 32(4), 689-706.

Dean, J. (2016). Crowds and Party. London: Verso.

Desmerais, A.A. (2007). La Via Campesina: Globalization and the Power of Peasants. London: Pluto Press.

Dussel, E. (2013). Ethics of Liberation. London: Duke University Press.

Fernandes, B.M., Welch, C.A. and Gonçalves, E.C. (2010). Agrofuel policies in Brazil, The Journal of Peasant Studies. 37(4): 793-819. 
Grosfoguel, Ramon. (2012). Decolonizing Western universalisms: Decolonial pluriversalism from Aimé Césaire to the Zapatistas. Transmodernity: Journal of Peripheral Cultural Production of the Luso-Hispanic World, 1(3): 88-104.

Hardt, M., and Negri, A. (2005) Multitude. London: Penguin.

Holt-Giménez, E. (ed.) (2010). Linking farmers' movements for advocacy and practice'. The Journal of Peasant Studies, 37(1): 203-236.

International Planning Committee for Food Sovereignty (IPC). About us. Available at: http://www.foodsovereignty.org/about-us/. Accessed on 27 May 2017.

Kiersey, N. and Vrasti, W. (2016). A convergent genealogy? Space, time and the promise of horizontal politics today. Capital \& Class, 40(1): 75-94.

Kinna, R. and Prichard, A. (in press). Anarchism and Non-Domination. Journal of Political Ideologies.

Laclau, E. and Mouffe, C. (1985). Hegemony and Socialist Strategy. London: Verso.

Land, Territory and Dignity Forum. (2006). For a new agrarian reform based on food sovereignty!. Available at https://nyeleni.org/spip.php?article54. Accessed on 10 August 2017).

Leventon, J. and Laudan, J. (2017). Local food sovereignty for global food security? Highlighting interplay challenges. Geoforum, 85: 23-26.

Maiguashca, B., Dean, J., and Keith, D. (2016). Pulling together in a crisis? Anarchism, feminism and the limits of left-wing convergence in austerity Britain. Capital \& Class, 40 (1): $37-57$.

Masson, D., Paulos, A. and Bastian, E.B. (2017). Struggling for food sovereignty in the World March of Women. The Journal of Peasant Studies, 44(1): 56-77.

Martínez-Torres, E. and Rosset, P. (2010). 'La Vía Campesina: the birth and evolution of a transnational social movement. The Journal of Peasant Studies, 37(1): 149-175.

Martínez-Torres, E. and Rosset, P. (2014). Diálogo de sabares in La Vía Campesina. The Journal of Peasant Studies, 41(6), 979-997.

Mignolo, W. (2002). The geopolitics of knowledge and the colonial difference. The South Atlantic Quarterly, 101(1): 57-96.

Mignolo, W. (2011). The Darker Side of Western Modernity. London: Duke University Press.

Motta, S. and Nilsen, A.G. (eds.) (2011). Social Movements in the Global South: Dispossession, Development and Resistance. London: Palgrave Macmillan. 
Mouffe, C. (2008). Critique as counter-hegemonic intervention. Transversal Texts, Available at http://eipcp.net/transversal/0808/mouffe/en. Accessed on 10 August 2017. Nyéléni. (2007). Nyéléni 2007 forum for food sovereignty. Available at https://nyeleni.org/DOWNLOADS/Nyelni EN.pdf, accessed on 10 August 2017.

Nyéléni Europe. (2016). Report of the Nyéléni Pan-European Forum. Available at http://nyelenieurope.net/publications/report-nyeleni-pan-european-forum-2016, accessed on 10 August 2017.

Park, C.M.Y, White, B., and Julia. (2015). We are not all the same: taking gender seriously in food sovereignty discourse. Third World Quarterly, 36(3): 584-599.

Prichard, A., Kinna, R., and Berry, D. (eds.) (2012). Libertarian Socialism: Politics in Black and Red. London: Palgrave Macmillan.

Prichard, A. and Worth, O. (2016). Left-wing convergence: an introduction. Capital \& Class, 40(1): 3-17.

Purwanto, H. (2013). Local to global: how Serikat Petani Indonesia has accelerated the movement for agrarian reform. Pp. 1-12 in La Vía Campesina ’s Open Book: Celebrating 20 Years of Struggle and Hope. Harare: Vía Campesina.

Rosset, P. (2011). The campesino-to-campesino agroecology movement of ANAP in Cuba. The Journal of Peasant Studies, 38(1), 161-91.

Rosset, P. (ed.) (2013). 'Re-Thinking agrarian reform, land and territory in La Vía Campesina. The Journal of Peasant Studies, 40(4), 721-775.

Rosset, P. and Martínez-Torres, M.E. (2012). Rural social movements and agroecology: context, theory, and process. Ecology and Society, 17(3).

Santos, B.d.S. (2008). The World Social Forum and the global left. Politics and Society, 36(2): 247-270.

Santos, B.d.S., Nunes, J.A. and Meneses, M.P. (2007). Introduction. Pp. xix-lxii in Santos, B.d.S. (ed.) (2007). Another Knowledge is Possible: Beyond Northern Epistemologies, London: Verso.

Starr, A., Martínez-Torres, E.M. and Rosset, P. (2011). Participatory democracy in action: practices of the Zapatistas and the Movimento Sem Terra. Latin American Perspectives, 38(1): 102-119.

Teivanen, T. (2016). Occupy representation and democratise prefiguration: speaking for others in global justice movements. Capital \& Class, 40(1): 19-36. 
La Via Campesina (LVC). (2009). Small-scale sustainable farmers are cooling down the earth. Available at http://viacampesina.org/downloads/pdf/en/EN-paper5.pdf, accessed on 25 June 2017.

La Vía Campesina (LVC). (2012). Bukit Tinggi declaration on agrarian reform in the $21^{\text {st }}$ Century. Available at https://viacampesina.org/en/bukit-tinggi-declaration-on-agrarianreform-in-the-21st-century/. Accessed on 04 October 2018.

La Via Campesina (LVC). (2017). VIIth International Conference press kit. Available at https://viacampesina.org/en/wp-content/uploads/sites/2/2017/05/VIIth-Conf-Press-

Kit_EN 12May.pdf. Accessed on 10 August 2017.

Vey, J. (2016). Crisis protests in Germany, Occupy Wall Street and Mietshäuser Syndikat. Capital \& Class, 40(1), 59-74.

Wittman, H. (2009). Interview with Paul Nicholson. Journal of Peasant Studies, 36(3), 676-682.

Wittman, H., Desmarais, A.A. and Wiebe, N. (2010). The origins and potential of food sovereignty. Pp. 1-14 in Wittman, H. Desmarais, Annette A., and Wiebe, N. (eds.). Food sovereignty: reconnecting food, nature and community. Halifax, NS: Fernwood Publishing.

World Bank. (2009). Awakening Africa's Sleeping Giants: Prospects for Commercial Agriculture in the Guinea Savannah Zone and Beyond. Washington DC: The World Bank.

Worth, O. and Buckley, K. (2009). The World Social Forum: postmodern prince or court jester?. Third World Quarterly, 30(4), 649-661. 